\title{
The Effect of Nutritional Status, Playing Activities, and Physical Fitness on the Motor Abilities of Children of Kubu Jambi Province
}

\author{
Gusril $^{1 *}$ and Wiladi Rasyid ${ }^{2}$ \\ 1,2 Lecturer at the Faculty of Sports Science, Universitas Negeri Padang \\ *Corresponding author.Email: gusrilnasir@yahoo.com
}

\begin{abstract}
This research aims to find whether the effect of nutritional status (X1), playing activities (X2) and physical fitness (X3) on the motor abilities. The research method used Path analysis. The populations of this research were the ethnic children in Kubu, Meranti Regency, Jambi Province. Samples were drawn using purposive sampling and obtained a sample of 30 people. The results of data analysis show that the path coefficient value is significant and linear, where the magnitude of the influence both directly and indirectly is as follows:(1) there is a direct effect of nutritional status

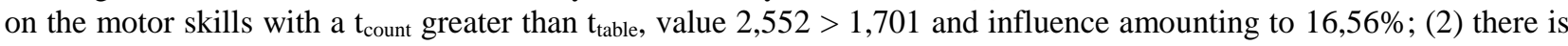
a influence between playing activities on the motor abilitiess with a $t_{\text {count }}$ greater than the $t_{\text {table }}$, the value of $2,453>$ 1.701 and a contribution of $16,97 \%$; ( 3) there is the influence of physical fitness on motor skills with a $t_{\text {count }}$ greater than the value of $t_{\text {table, }}$, the value of $1,843>1.701$ and a influence of $9,54 \%$; 4) there is an indirect effect of nutritional status through physical fitness on the motor abilities with a $t_{\text {count }}$ greater than the value of $t_{\text {table, value }} 1,805>1.701$ and a influence of $24,44 \%$; and (5) there is an indirect effect of playing activities through physical fitness on motor skills with a $t_{\text {count }}$ greater than the $t_{\text {table, }}$, the value of $3,236>1.701$ and a influence of $0,41 \%$.
\end{abstract}

Keywords: Nutritional status, playing activities, physical fitness, motor ability

\section{INTRODUCTION}

Motoric ability basically cannot be separated from doing movement activities; they are two things that are interrelated. The amount of exercise or movement experience will improve students' motor skills. Students' motor skills are influenced by internal and external factors.

The nutritional status of students is internally represented by their physical condition which can be measured by their weight and height. The development of motor skills will be optimal if the child has a good nutritional status. Rahmawati and Marfuah (2016) explain that good nutritional status can occur if the body gets enough nutrients that are used efficiently, so as to allow physical growth, brain development, and work ability to achieve optimal health levels. Gusril (2017) explains that good nutritional status makes children's motor perceptions develop well and can carry out maximum daily activities.

Another factor that affects a person's motor skills is physical fitness. These factors are grouped into physical factors (Gusril, 2017) which states that physical fitness can be described as a person's hysical condition in carrying out daily activities without any obstacles. Elementary school students usually do alot of movement activities, especially in playing. However, physical fitness is also closely related to a person's nutritional status.

The motor skills of children can grow and develop well if the child was various experiences of movement. Children can experience various kinds of movement if their nutritional needs are met. By fulfilling the nutritional needs of children, they will have a good nutritional status. Children who have good nutritional status will have good endurance and will look agile, active, and always enthusiastic in participating in various activities. Thus the child will gain a broad experience of movement, so that it will affect the child's motor development. Vice versa, poor nutritional status in children can result in children's motor development that is not optimal.

Playing activities are physical activities that involve children's movement and imagination. For children playing is not only a way to get pleasure, directly and without realizing it the benefits of playing are the same as sports for children. In this case, motor skills are triggered by physical acitivity in the form ofplaying. 
The components of physical fitness are related to skills in which there are several elements of phsical condition. If the elements of physical fitness are in good condition, then their motor skills are also good. This is because motor skills always involve physical elements in it. The level of physical fitness and motor skills are interrelated components.

Consumption of food that is pursued by traditional tribesmen and different places, in addition to affecting nutritional status, it will also affect the physical fitness of these traditional tribes. For example, body composition, which is one component of physical fitness and influences the decline in ability caused by heart disease and obesity (Syahara, 2011).

Changes in lifestyles in traditional societies then have an efect on food consumption patterns, which in turn affect the nutrition status of these communities. Apart from nutritional status, phsical fitness and playing activities have also changed.

\section{METHOD}

This research is quantitative research, namely Comparative Causal. The population of this research is ethnic children in Kubu, Meranti Regency, Jambi Province. The samples were drawn using purposive sampling and obtained 30 people. The instrument measures the nutritional status of children, namely: weight scales and height gauges, playing activities using a Likert scale qustionnaire, physical fitness using the Harvard Step Test and motor skills using a modified Scoot Motor Ability Test. Data analysis techniques using Path Analysis.

\section{RESEARCH RESULT}

Based on data analysis and the results of hypothesis testing, it shows that the dependent variable (Y) the motor skills of the Tribe of children in the Kubu are explained as follows:

\subsection{There is a direct effect of nutritional status on motor skill}

In the calculation of path analysis, it was found that there was a direct effect of nutritional status $\left(\mathrm{X}_{1}\right)$ on motor ability $(\mathrm{Y})\left(\rho_{\mathrm{yx} 1}\right)=0,407$ and the $\mathrm{t}_{\text {count }}$ score was greater than the $t_{\text {table }}$ score, the score of 2,552 > 1,701. It turns out that there is a direct effect of nutritional status on the motor skills of ethnic children in Kubu, Jambi Province.

Sa'adah, et al. (2014) stated that nutritional status is a major determining factor for the quality of human resources; a good nutritional status will affect the process of child growth and development. Nutritional status is one of the main factors affecting children's motor skills.
The results of Astyorini's (2014) study showed that there was a significant influence in the moderate category between nutritional status on motor skills of elementary school schildren. At school age, physical and social growth and development of their physical activities especially the development of motor skills.

The nutritional status and motor skills on elementary school students need to be considered. Fulfilling the needs of good nutrition can support the moto skills of students who influence their future lives. Meeting good nutritional needs will not only affect the cognitive domain, but also the psychomotor domain.

Sa'adah, et al. (2014) stated that nutritional status is a major determining factor for the quality of human resources; a good nutritional status will affect the process of child growth and development. In this case, one of them is motor skills, especially children who are in their infancy, namely elementary school children. Nutritional status is one of the main factors affecting children's motor skills

The results of Astyorini's (2014) study state that there is a significant influence in the moderate category between nutritional status on motor skills of elementary school children. At school age, physical and social growth occurs rapidly, so that at this age children need more nutrition to support the growth and development of their physical activities, especially the development of motor skills.

\subsection{There is a direct effect of playing activities on motor skills}

In the calculation of path analysis, it was found that there was a direct effect of laying acitivity $\left(\mathrm{X}_{2}\right)$ on motor skills (Y) $\rho_{\mathrm{YX} 2}=0,412$. Based on the results ofthe calculations carried out, the score of $\mathrm{t}_{\text {count }}$ is greater than the score of $t_{\text {table, }}$, the score $2,453>1,701$. Playing activities have a direct effect on the motor skills of ethnic children in Kubu.

That playing is a practical education for children without realizing it. This continues over a relatively long period of time, thus forming a motor ability that continues to develop and is trained without the child's awareness.

Saputra and Fantiro (2017) explain that their daily activities during school breaks are always filled with dynamic play activities. It is very clear that students in elementary schools are always moving with the elements involved: speed, agility, strength. They can also do activities for a long time without feeling tired, sometimes even doing more than one game.

Tatli (2018) in Turkey on grade 5-8 students about playing activities shows the results that girls prefer to play outdoor games while boys prefer to play digital games. Participating students prefer to play rule 
games outdoors and symbolic games indoors, and in a digital environment, girls prefer to play mini games whereas boys prefer to play sports games. Playing is basically doing activities both actively and passively. This will have an impact on his motor skills, especially games that are sports.

In line with Fadilah and Wibowo (2017), game activities consist of various movement abilities and playing abilities that students must master in order to gain success in a game. Likewise, with the theory put forward by Pellegrini in Ericsson (2016) which found that sports games (with gross motor movements) increased and reached their peak during elementary school. However, basic motor skills can be an important factor in motivation to be physically active and be able to participate in physical and social play.

The same thing is also explained by Mclnnes \& Birdsey in Tatli (2018), which explains that games prepare children physically and cognitively for life and they are tools that enhance their creativity, develop their problem-solving skills and increase their feelings of freedom. There is great potential for using games as a learning environment.

Games are fun activities that consist in their essence the main intrinsic motivational factor that catches the learner's attention and makes him persistent and enthusiastic about the activity. Therefore, games are recognized as a valuable tool in instructional design that seeks to create an engaging and educational learning environment. Stojanovska et al. (2014). According to Sujiono (2013) learning through play can develop various potentials in children, not only physical or motoric but also cognitive, language, social, emotional, creativity and ultimately academic achievement. Playing activities are an important part because they are motion activities that train and support the development of their motor skills.

\subsection{There is a direct effect of Physical Fitness on Motor Ability}

In the calculation of path analysis, it was found that there was a direct effect of physical fitness $\left(\mathrm{X}_{3}\right)$ on motor ability (Y) $\rho_{\mathrm{YX} 3}=0,309$. Based on the results of the calculations carried out, the score of $t_{\text {count }}$ is greater than the score of $t_{\text {table, }}$ the score is $1,843>1,701$. So, physical fitness has a direct effect on the motor skills of tribal children in Kubu, Jambi Province.

The effect of physical fitness on the motor skills of ethnic children in Kubu Jambi Province is $11.56 \%$, while the remaining $88.44 \%$ is influenced by other factors.

A person who is able to carry out daily life without exceeding the stress resistance limits of the body and has a healthy body and is not at risk of experiencing diseases caused by low levels of fitness or lack of physical activity is defined as someone who is fit in relation to sports and physical activity (Mood, et al. al. in Sukamti, et al., 2017).

Physical fitness in this study has the greatest influence on motor skills. Students with good physical fitness will be able to do any activity without feeling tired, which in turn will affect the motor skills formed through these activities.

A person who is able to carry out daily life without exceeding the stress resistance limits of the body and has a healthy body and is not at risk of experiencing diseases caused by low levels of fitness or lack of physical activity is defined as someone who is fit in relation to sports and physical activity (Mood, et al. al. in Sukamti, et al., 2017.

The results of this study are supported by Wijayanto and Muhammad (2014), physical fitness has a function to develop strength, ability, and ability to create and endurance. This means that by having good physical fitness, students can train their motor skills with physical activity or planned or unplanned movements.

Sukamti, et al. (2016) explained that physical fitness can be influenced by age, gender, heredity, diet, smoking habits, and exercise. In terms of food, the consumption pattern that is applied will affect the nutritional status of a person, thus affecting one's physical fitness.

\subsection{There is an indirect effect given by nutritional status through physical fitness on motor skills \\ In the calculation of the path analysis, it was} found that there was an indirect effect of nutritional status $\left(\mathrm{X}_{1}\right)$ through physical fitness $\left(\mathrm{X}_{3}\right)$ on motor ability (Y), which was obtained from the result of the path coeficient $\rho_{x 31}=0,283, \rho_{\mathrm{yx} 3}=0,309$. From the $\mathrm{t}_{\text {count }}$ score, the score is $1,805>1,701$. So, nutritional status indirectly affects motor skls through physical fitness.

\section{DISCUSSION}

In this case, the nutritional status, namely the pattern of daily food consumption, has a direct effect on physical fitness by $10.56 \%$. Rahmawati (2016) stated that children at primary school age have more activities, both at school and outside of school. Hence, the children need more energy. Meanwhile, physical fitness is the condition of a person's body that is able to carry out daily activities without feeling tired or stressed and can even do other things outside of his daily activities.

This is in line with what was stated by Sukamti, et al. (2016) that physical fitness can be affected by age, gender, heredity, diet, smoking habits, and exercise. In terms of food, the consumption pattern that is applied 
will affect the nutritional status of a person, thus affecting one's physical fitness.

Good motor skills cannot be obtained just like that, there are supporting factors. Physical fitness is closely related in developing motor skills. Physical fitness is also obtained from a good nutritional state, one of them. This means that there is an indirect effect that nutritional status has on motor skills through physical fitness. Students with good nutritional status will have good physical fitness, which then can have good motor skills as well.

Parents' knowledge and economic conditions are one of the nutritional factors for tribal children in the Jambi Province Kubu. Based on the visits of researchers to several houses where they lived, it was found that their parents lacked knowledge about proper nutritional consumption. This is in line with (Anzarkusuma, et al., 2014) which states that elementary school children are one of the groups that are prone to experiencing malnutrition, among which the causes are low economic levels and unbalanced food intake and low parental knowledge.

\subsection{There is an indirect effect given by playing} activities through physical fitness on motor skills

In the calculation of path analysis, there is an indirect effect of playing activity (X2) through physical fitness (X3) on motor ability (Y), which is obtained from the path coefficient product $\rho \times 32=0.508$, $\rho y \times 3=$ 0.309. Based on the results of the analysis, it is obtained that the $t_{\text {count }}$ score is greater than the $t_{\text {table }}$ score, the score is 3.236> 1.701. So, playing activities have an indirect effect on motor skills through physical fitness.

Apart from nutritional status, physical fitness is also influenced by playing activities. Physical fitness based on research data is mostly in the good and poor categories. However, this cannot be separated from the influence of ethnic children playing activities in sakai. Moreover, the playing activities of ethnic children in Kubu are not only at school, but also outside of school.

Playing activities affect the physical fitness of the children in the Kubu, the more play activities are carried out, the higher the physical fitness of the children to do other activities. However, playing activities that are carried out are physical activities or overall movements that indirectly affect motor skills through physical fitness.

The results of this study are supported by the theory put forward by Chen et al. (2015), explained that cross-sectional studies have found a positive relationship between basic motor skills competencies and physical activity in children. Likewise, Stodden et al. in Chen et al. (2015) who proposed a reciprocal relationship and dynamic development between motor skills competency and physical activity.

\section{CONCLUSION}

Based on the research results that have been stated previously, it is known that nutritional status, play activities and physical fitness have a significant effect on the motor skills of ethnic children in Kubu Jambi Province.

\section{ACKNOWLEDGMENT}

This research was carried out with assistance from the Ministry of Education and Culture's DPRM Fund. In addition, thank you to the head of LP2M UNP, students, lecturers of FIK UNP, Social Service of Meranti Regency and Tumenggung and ethnic children in Kubu, Jambi Province.

\section{REFERENCES}

[1] Agus Irianto. (2007). Statistika Konsep Dasar dan Aplikasinya. Jakarta: Kencana.

[2] Alpyan, Raja T. 2018. The Existence of Traditional Games in Meeting the Need of Motoric Development Paticipating. Proceeding The 3rd International Conference on Education-Teachers in The Digital Age. Batu Sangkar: Fakultas Tarbiyah dan Ilmu Keguruan IAIN Batusangkar.

[3] Amanda MZ, Neola, dkk. 2015. Pengaruh Status Nutrisi Terhadap Kebugaran Fisik Atlit Karate Di Bandar Lampung. J MAJORITY Volume 4 Nomor 6 Maret 2015, Hal. 1-4.

[4] Anzarkusuma SI., \& Mulyani YE. Jus'at I. (2014) Status gizi berdasarkan pola makan anak sekolah dasar di Kecamatan Rajeg Tangerang. Indonesian Journal of Human Nutrition. 2014; 1(2) Hal : 135 148.

[5] Anwar, Faisal., \& Riyadi, Hadi. Status Gizi dan Status Kesehatan Suku Baduy (Nutrition and Health Status of Baduy Tribe). Jurnal Gizi dan Pangan, Juli 2009 4(2): $72-82$.

[6] Alamsyah, Nurul, DA. (2017). Faktor-Faktor Yang Berhubungan Dengan Kebugaran Jasmani Pada Remaja Siswa Kelas Xi Smk Negeri 11 Semarang. Jurnal Kesehatan Masyarakat (E-Journal) Volume 5, Nomor 3, Juli 2017 (ISSN: 2356-3346). Hal 7786.

[7] Ardiyansyah, Firman. 2016. Kemampuan Motorik Dasar Siswa Kelas Iv Dan V SD N Keraton Yogyakarta Tahun Ajaran 2015/2016. Jurnal Kemampuan Motorik Dasar Tahun 2016, http://journal.student.uny.ac.id/ojs/index. php/pgsdpenjaskes/article/viewFile/2909/2517. Hal. 1-9.

[8] Astyorini, Dwi Y. 2014. Hubungan Status Gizi Terhadap Kemampuan Motorik Kasar Anak Sekolah 
Dasar Kelas 1 Di SDN Krembangan Utara I/56 Surabaya. Jurnal Kesehatan Olahraga Volume 02 Nomor 02 Tahun 2014, Hal. 33-39

[9] Asrar, Muhamad., dkk. (2009). Pola Asuh, Pola Makan, Asupan Zat Gizi dan Hubungan dengan Status Gizi anak Balita Masyarakat Suku Nuaulu di Kecamatan Amahai Kabupaten Maluku Tengah Provinsi Maluku. Jurnal Gizi Klinik Indonesia Vol. 6, No. 2, November 2009; 84-94.

[10]Badu, Ruslin. (2013). Pengembangan Model Pelatihan Permainan Tradsional Edukatif Bebasis Potensi Lokal Dalam Meningkatkan Kemmpuan dan keterampilan Orang Tua Anak Usia Dini di PAUD Kota Gorontalo. Jurnal Penelitian dan Pendidikan, volume 8 nomor 1, Maret 2011. Hal.70-77.

[11] Bryantara, OF. (2016). Faktor Yang Berhubungan Dengan Kebugaran Jasmani (Vo2 Maks) Atlet Sepakbola. Jurnal Berkala Epidemiologi, Vol. 4 No. 2, Mei 2016: 237-249.

[12]Chen et al. 2015. Motor Skill Competency and Physical Activity in Elementary School Students. International Journal of Humanities Social Sciences and Education (IJHSSE) ISSN 2349-0373 (Print) \& ISSN 2349-0381 (Online) www.arcjournals.org Volume 2, Issue 4, April 2015, Page 76-83.

[13]Darmawan, Ibnu. 2017. Upaya Meningkatkan Kebugaran Jasmani Siswa Melalui Penjas. JIP, Vol.7, No. 2, Edisi Agustus 2017, http://ejournal.unikama.ac.id/ index.php/jrnspirasi, Hal. 143-154.

[14] Depkes. 2005. Riset Kesehatan Dasar 2006. Jakarta.

[15]Depkes RI. 2000. Panduan Penggunaan Kartu Menuju Sehat (KMS) Balita bagi Petugas Kesehatan. Direktorat Gizi Masyarakat. Jakarta.

[16]Deswari, Nuri. (2016). Hukum Adat Sebagai Wujud Kearifan Lokal Masyarakat Adata Talang Mamak Di Riau. Etnopedagogy The Proceding Of International Seminar On Etnopedagogy. Banjarmasin: FKIP Unlam press. Hal. 855-864.

[17]Ericsson IR. 2014. Effects of motor skills training and daily physical education; Research results in the Swedish Bunkeflo project. International Journal of Physical

Education https://www.researchgate.net/publication/30626375 2. Page 1-12.

[18]Fadilah, Mei \& Wibowo, Ricky. 2018. Kontribusi Keterampilan Gerak Fundamental Terhadap Keterampilan Bermain Small-Sided Handball Games. Jurnal Pendidikan Jasmani dan Olahraga. http://ejournal.upi.edu/index.php/penjas/index, JPJO 3 (1) (2018), Hal. 60-68.

[19]Gusril. (2017). Perkembangan Motorik Pada Masa Anak-Anak. Padang: UNP PRESS.
[20]Hadi, Sutrisno. 1991. Analisa Butir untuk Instrumen. Edisi Pertama. Yogyakarta: Andi Offset.

[21]Hasanah, Uswatun. (2016). Pengembangan Kemampuan Fisik Motorik Melalui Permainan Tradisional Bagi Anak Usia Dini. Jurnal Pendidikan Anak, Volume 5, Edisi 1, Juni 2016. Hal. 717-733.

[22]Hidayanti, Maria. 2013. Peningkatan Kemampuan Motorik Kasar Anak Melalui Permainan Bakiak. Jurnal Pendidikan Usia Dini Volume 7, Edisi 1 April 2013 Hal. 195-200.

[23]Irianto, DP. (2017). Pedoman Gizi Lengkap Keluarga \& Olahragawan. Yogyakarta: ANDI OFSET

[24]Kadir. 2015. Statistika Terapan : Konsep, Contoh, dan Analisa Data dengan Program SPSS/Lisrel dalam Peneltian. Jakarta : PT Rajagrafindo

[25]Khairuddin. (2016). Penerapan Ilmu Gizi Dalam Aktivitas Olahraga. Padang: Suka Bina Press.

[26]Kopeikina E.N et al. 2016. Modification of Harvard Step-Test for Assessment of Students' With Health Problems Functional Potentials. Journal of PHYSICAL EDUCATION OF STUDENTS doi:10.15561/20755279.2016.0405. page 44-50.

[27]Kusumawati, Oktaria. 2017. Pengaruh Permainan Tradisional Terhadap Peningkatan Kemampuan Gerak Dasar Siswa Sekolah Dasar Kelas Bawah. TERAMPIL Jurnal Pendidikan dan Pembelajaran Dasar Volume 4 Nomor 2 Oktober 2017 p-ISSN 2355-1925 e-ISSN 2580-8915, Hal. 124-142.

[28]Hidayanti, Maria. (2013) Peningkatan Kemampuan Motorik Kasar Anak Melalui Permainan Bakiak Maria Hidayanti. Jurnal Pendidikan Usia Dini Volume 7, Edisi 1 April 2013 Hal. 195-200.

[29]Kanjilal et al. 2010. Nutritional status of children in India: household socio-economic condition as the contextual determinant. International Journal for Equity in Health · August 2010 DOI: 10.1186/14759276-9-19 - Source: PubMed page 1-13.

[30]Mandal et al. 2017. An assessment of nutritional status of children aged 0-14 years in a slum area of Kolkata. International Journal of Medicine and Public Health | Apr-Jun 2014 | Vol 4 | Issue 2 Page 159-162.

[31]Marhamah, dkk. 2014. Perilaku Konsumsi Dan Status Gizi Anak Sekolah Dasar Di Kota Serang. Jurnal Matematika, Sains, dan Teknologi, Volume 15, Nomor 2, September 2014, 97-105.

[32]Nurhasan. (2004). Penilaian Pembelajaran Penjas. Jakarta: Depdiknas.

[33]Ningsih, Dewi. (2017). Perubahan Sosial Budaya Suku Sakai Kampung Minas Barat Kecamatan Minas Kabupaten Siak. JOM FISIP Vol. 4 No. 2 , Oktober 2017 Hal. 1-12. 
[34]Nuzrina, Rachmanida., dkk. (2016). Penilaian Status Gizi Anak Sekolah Dasar Duri Kepa 11 Menggunakan Indeks Tinggi Badan Menurut Umur Dan Indeks Massa Tubuh Menurut Umur. Jurnal Abdimas Volume 3 Nomor 1, September 2016. Hal. 62-67.

[35]Pahlevi, Andriani E. 2012. Determinan Status Gizi Pada Siswa Sekolah Dasar. Jurnal Kesehatan Masyarakat, KEMAS 7 (2) (2012). Hal. 122-126.

[36]Rahmawati, Tuti, \& Marfuah, Dewi. (2016). Gambaran Status Gizi Pada Anak Sekolah Dasar The Description Of Nutritional Status Of Children At Primary School. Profesi, Volume 14, Nomor 1, September 2016. Hal. 72-76.

[37]Ramadhana, MML \& Prihanto, JB. 2016. Hubungan Antara Status Gizi Dengan Tingkat Kebugaran Jasmani Siswa Disma Negeri Plandaan Jombang. Jurnal Pendidikan Olahraga dan Kesehatan Volume 04 Nomor 02 Tahun 2016, Hal. 467 - 471.

[38]Riduwan \& Kuncoro, AE. 2012. Cara Menggunakan dan Memakai Path Analysis. Bandung: Alfabeta.

[39]Rowicka et al. (2017). Diet and Nutritional Status of Children with Cow's Milk Protein Allergy, Treated with a Milk-Free Diet. International Journal of Allergy Medications Int J Aller Medications 2017, 3:025 ISSN: 22572-3308 Volume 3 | Issue 1 Open Access DOI: 10.23937/2572-3308.1510025. Page 18.

[40]Sa'adah, dkk. 2014. Hubungan Status Gizi dengan Prestasi Belajar Siswa Sekolah Dasar Negeri 01 Guguk Malintang Kota Padangpanjang. Jurnal Kesehatan Andalas. 2014; 3(3) http://jurnal.fk.unand.ac.id, Hal. 460-465.

[41]Santrock, John W. (2012). Life-span Development. 13 th Edition. University of Texas, Dallas : Mc Graw-Hill.

[42]Saputra, Yunus S \& Fantiro, FA. 2017. Permainan Motorik Untuk Sekolah Dasar. Prosiding SENASGABUD http://researchreport.umm.ac.id/index.php/ SENASGABUD (Seminar Nasional Lembaga Kebudayaan) Edisi 1 Tahun 2017, Hal. 149-155.

[43]Soemitro. (1991). Permainan Kecil. Jakarta: Depdikbud.

[44]Stojanovska TV. et al. 2014. The Educational Prospects of Traditional Games as Learning Activities of Modern Students. https://www.researchgate.net/publication/ 272127194 Conference Paper · October 2014.

[45]Sugiyono. 2010. Metode Penelitian Pendidikan (Pendekatan Kuantitatif, Kualitatif, dan $R \& D$ ). Bandung: Afabeta.
[46]Sujiono. 2013. Konsep Dasar Pendidikan Anak Usia Dini. Jakarta: PT. Indeks.

[47]Sukamti, ER., dkk. (2016). Profil Kebugaran Jasmani Dan Status Kesehatan Instruktur Senam Aerobik Di Yogyakarta. Jurnal Olahraga Prestasi, Volume 12, Nomor 2, Juli 2016 Hal. 31-40.

[48]Sukardi. 2003. Metodologi Penelitian Pendidikan. Jakarta; Bumi Aksara.

[49]Syahara, Sayuti. (2011). Pertumbuhan \& Perkembangan Fisik-Motorik. Padang. Fakultas Ilmu Keolahragaan Press.

[50]Tatli, Zeynep. 2018. Traditional and Digital Game Preferences of Children: A Chaid Analysis on Middle School Students. Contemporary Educational Technology, 2018, 9(1), page 90-110.

[51]Terati, Nilawati, N.S ; Fatonah, R.D. (2011). Faktor - Faktor Yang Berhubungan Dengan Status Gizi Balita Usia 06-60 Bulan Di Kelurahan Kuto batu Kecamatan Ilir Timur II Kota PalembangTh 2011.

[52]Tedja Saputra, Mayke S. 2001. Bermain, Mainan dan Permainan. Jakarta: Grasindo.

[53]Trianto. 2010. Pengantar Penelitian Pendidikan Bagi Pengembangan Profesi Pendidikan dan Tenaga Kependidikan. Jakarta; Kencana.

[54]Wijayanto, Yuyud \& Muhammad Nur H. 2014 Hubungan Antara Tingkat Kesegaran Jasmani Dengan Keterampilan Motorik (Kelincahan) Di SMP Negeri Satu Atap Jabon (Studi pada Kelas VII). Jurnal Pendidikan Olahraga dan Kesehatan Volume 02 Nomor 02 Tahun 2014, http://ejournal.unesa.ac.id/index.php/jurnalpendidikan-jasmani/issue/ archive, Hal. 345 - 349.

[55]Winarno. 2013. Metode Penelitian Dalam Pendidikan Jasmani. UNP: UM Press.

[56]Yulia, Cica. 2017. Revitalisasi Pemberian Makanan Tambahan Dan Integrasi Pendidikan Gizi Berbasis Kearifan Lokal Di Sekolah Sebagai Upaya Perbaikan Gizi Anak Usia Sekolah. Jurnal Media Pendidikan, Gizi dan Kuliner. Vol. 6, No. 1, April 2017. Hal. 18-33.

[57]Yusuf, Havid. 2018. Evaluasi Kebugaran Jasmani Melalui Harvard Step Test pada Mahasiswapjkr Tahun 2016/2017 Ikip Budi Utomo. Jp.jok (Jurnal Pendidikan. Jasmani, Olahraga dan Kesehatan) Volume 1, Nomor 2, Mei 2018 P-ISSN 2613-9421,

Hal. 1-13. 